\title{
Philosophies of Digital Pedagogy
}

\author{
David Lewin ${ }^{1} \cdot$ David Lundie ${ }^{2}$
}

Published online: 22 February 2016

(c) Springer Science+Business Media Dordrecht 2016

This special issue draws attention to an emerging field of study, combining the philosophy of technology and information theory, with critical pedagogy and educational philosophy. It builds upon a conference sponsored by the Philosophy of Education Society of Great Britain: Humanising Online Pedagogy hosted by Liverpool Hope University (Liverpool, UK) in May 2014. The conference brought together educational practitioners and philosophers to explore the pedagogical, epistemic, social, and philosophical implications of technological change for educators. Papers included perspectives from adult education, learning disabilities, information theory, and global perspectives on the ethics of technology. As well as including versions of some papers presented here, the special issue also includes invited contributions from authors across the philosophy of educational technology debate. This issue also features an interview with Bernard Stiegler, a leading figure in contemporary philosophy of technology, whose recent work locates him directly among debates within educational theory and practice. The debates developed in this issue demonstrate the on-going significance of philosophy and educational theory to practical, even apparently 'technical' issues, calling to mind long-standing concerns raised by figures such as Jacques Ellul, Martin Heidegger, Herbert Marcuse and other so-called 'classical philosophers of technology' (Achterhuis 2001), that questions of technique are seldom only technical, but bear upon wider practical, philosophical, ethical and spiritual matters.

Education tends to draw its conception of technological change from the prevailing cultural milieu. Consequently, education is given to stories of the transformative power of

David Lewin

david.lewin@strath.ac.uk

David Lundie

lundied@hope.ac.uk

1 University of Strathclyde, Glasgow, UK

2 Liverpool Hope University, Liverpool, UK 
technology in education (Plowman and McPake 2013). The promise that digital education will revolutionise teaching and learning through, for example, the wide availability of digital learning resources or radically restructured virtual learning experiences, often passes without comment on the problematic social, ethical and epistemic assumptions underpinning such changes. Concerns about potential 'future shock'-from Toffler's theory of disorientation and alienation as a product of excessive social and technological change (Toffler 1970) to Kaplan's ideas around the obsolescence of human intellectual labour (Kaplan 2015) — have not suppressed our appetite for progress. Indeed education seems wedded to conceptions of social and individual (if not quite technological) progress that often go unexamined.

While digital devices have long since become embedded in contemporary life, our social, cultural and particularly our educational institutions are struggling to keep up with the pace of change. This suggests a separation between what we can do with technology, and how we understand our enlarged capacities within the lifeworld of our institutions; it suggests what Günther Anders once called a discrepancy between production and conception which "signifies that in a terrible sense we "know no longer what we do", (Lewin 2010). That we know not what we do was of great concern to Anders in 1957 with the emergence of the Cold War and the nuclear arms race. But perhaps the disproportion between action and conception is of greater significance still to present educational contexts. Failing to understand the implications our own actions is a concern, but embedding that blindness, making that blindness a structural feature of inattentive and procedurally focused systems of education, threatens to reinforce and extend that myopia.

While virtual learning environments, MOOCs and the like are generating a great deal of interest, it is less clear that they are provoking sufficient pedagogical and philosophical reflection (Boyatt et al. 2014; University of Edinburgh MSc in E-learning 2011). This is partly because of the widely held assumption that technologies are tools, fundamentally neutral with respect to the purposes for which they are developed or to which they are applied. Tools, so it is assumed, do not in themselves imply a set of commitments, values or any particular way of being. Problematizing this assumption, the papers in this collection address a range of devices, platforms and affordances which stand poised to colonize the educational space. These include the massive open online course (Knox 2016), mobile internet associated technologies such as tablets and smartphones (Davies 2016) which are now ubiquitous in classrooms, and learning analytics software (Lundie 2016) which promises to measure educational outcomes and efficacies with ever increasing granularity.

The philosopher who has done more than most to disabuse us from this instrumental conception of technology is Martin Heidegger whose influence can be detected directly or indirectly (through Derrida, Stielger and others) among the authors of these articles. While Heidegger's later work did much to inaugurate the philosophy of technology as a subdiscipline of philosophy, there is no straightforward alignment here with his views, or indeed with any school or tradition among the authors of this issue. Although many philosophers have extended Heidegger's analysis of technology, disputing the presumed ideological neutrality of technology (Ellul 1964; Green 2002; Lewin 2012), the presumption of technological neutrality remains commonplace: many legal and pedagogical innovations still presuming technology to be ethically neutral (Alder 1998; Green 2002). Recent developments in the philosophy of information and computing, however, have begun to acknowledge the importance of philosophical reflection at the design level (Lewin 2013; Lundie 2015; Wicker and Schrader 2010) although the application of these directions to philosophies of education remains nascent. 
Of course, even techno-optimists acknowledge that there may be problems with the impact of certain specific technologies and that precautionary approaches offer a corrective to over-zealous utopianism. Here it is assumed that there is no question concerning technology in principle, only in specific contexts. Where technology in principle does become questionable, it is too often vilified as hubristic, deterministic or nihilistic. A generalised suspicion of technology is as unhelpful as the thoughtless assumption that technology is unequivocally good. This kind of polarisation is reinforced by a settled range of binaries: the natural against the artificial; the organic against the synthetic; the discovered against the invented. The polarisation restricts sustained reflection on the complex and often ambivalent nature of technological change. Now more than ever such sustained reflection is needed.

The work of Bernard Stiegler is pertinent here. His rise to prominence within Continental philosophy and philosophy of technology results from his sustained and creative engagement with his intellectual forebears, figures such as Husserl, Heidegger, Derrida, Simondon and Deleuze. Stiegler's work came to particular prominence in the late 1990s and early 2000s through his 3-volume Technics and Time. More recently Stiegler has applied his insights to education in varied ways: as a wider philosophical conception of civic and political engagement, of individual and social formation (what Stiegler calls 'individuation') as well as a concern for intellectual and cognitive development, and the impact of digital cultures on that development (Stiegler 2012). This concern has a direct bearing on the educative purpose of 'subjectification', or the coming into presence of the individual in society (Biesta 2005). Philosophers of education have begun to draw on this body of work (Bradley 2015; Kouppanou 2015) and this special issue continues in that vein. In a thoughtful engagement with Stiegler's account of space and time, Jeremy Knox (2016) contends that a liberal-modernist orthodoxy of the university is maintained and structured into the new temporal relations of higher learning in the MOOC. Such preservation of cultural memory, Lewin (2016) argues, is a necessary prerequisite to culture, indeed in Stiegler (1998) to hominization, and is coeval with technologies of memory. Drawing on a Hegelian, rather than a Heideggerian conception of time, Lundie (2016) goes on to problematize the relational element of subjectification or self-becoming in digitally mediated pedagogies, while Bojesen (2016) highlights the importance of temporality to investigating whether the 'invention of the educational subject' by technology is a unique individual or a deterministic prescription.

If Stiegler's work engages the authors in this collection in considering subjectification, then the work of Luciano Floridi urges us to consider the conceptual apparatus used to frame the essential ground of the subject. Floridi's work problematizes the distinction between human and artificial intelligence, proffering a definition of 'informational organisms' (Floridi 2013) such that both may be the subject of a common ontological and ethical framework. Beginning at the level of abstraction of data and its basic definitions in information theory, Lundie (2016) challenges this characterisation, setting up a fundamental incompatibility between the information processor and the educational subject on the basis that the latter is not left unchanged by the 'data' it processes. Bojesen offers a possible resolution to this problem, highlighting that Floridi's informational ontology implies an 'inventing or prescribing the fiction of unity' to informational organisms-both human and artificial (Bojesen 2016; Floridi 2011a). Beginning instead from the human end of the interaction, Davies (2016) draws upon the concept of 'technobiophilia' (Thomas 2013) to argue that the natural is already latent in our conceptualisation of the technical, introducing bias both in the design and use of ccloud... stream... [and the landscape of] cyberspace' (Davies 2016, [2]). 
Despite the interest in digital cultures, reports of the impending death of the traditional classroom have been greatly exaggerated. Alongside a suspicion of the long-term impacts of networked living (Richtel 2011; Stiegler 2010), wider concerns about the impact of digitisation on educational institutions and processes are being expressed. In addition to the impact of MOOC's on 'traditional learning' (a phantastical phrase likely referring to a nonexistent origin) in higher education, Jan Masschelein and Maarten Simons (2013, Introduction), for example, have speculated that modern technologies threaten the institution of schooling as such since networked learning transfers most aspects of teaching and learning to the hands of the learners, thereby eroding the role of the teacher. This concern is related to the critical analysis of discourses of learning where constructivist learning paradigms seem to privilege the role of learning at the expense of teaching (Biesta 2006). Tendencies towards overstatement are strong: online learning cultures foretell the end of schooling; the end of the university is nigh. This special issue will frustrate all such simplistic narratives, drawing the reader into the complex and creative ambivalences that portray more faithfully the experience of practitioners: educators, students, technologists and philosophers.

The issue opens with an interview with Bernard Stiegler in which the significance of digital culture for the formative and transitional phases of childhood is discussed. In her questioning, Kouppanou draws out the anthropological and ontological issues that are encountered when digital culture is considered in Stiegler's terms. The discussion clearly demonstrates the divergence of Stiegler's thinking from Heidegger. It then moves on to consider the nature of learning as individuation and the role of teaching, and the different ways in which young people enter into culture in the digital age. Despite the deep concerns that are evident here, the discussion ends on an optimistic note whereby necessity is invoked as the agent of both formation and transformation.

Lewin's article seeks to question the often unconscious polarisations between the natural and artificial than exist within educational theories and practices. Drawing on Stiegler's analyses of memory and attention, Lewin explores what kinds of inattention modern technological culture encourages. He argues that attention has a capacity to mitigate some of the more excessive and pathological aspects of modern technology, and suggests that philosophers of religion might offer distinctive insights into the nature of attention and how technologies might form or disrupt it. Bojesen is similarly interested in the formative power of modern technologies. Inspired by Derrida and Stiegler, Bojesen's paper is concerned with the formation of the subject in the digital age in which, he argues, that our educational subjectivity has always been technological. Rather than offering a new definition of subjectivity for the digital age, Bojesen shows why definitions of subjectivity are themselves always already constrained by the technology of language itself, and seeks instead a reinvention rather than a prescription of subjectivity. Lundie's paper problematizes information theoretic conceptions of knowledge transmission, arguing for the need to understand the impact of technological structures on the way learners value the learning experience. Returning again to the theme of the subject, Lundie argues that the complex ambivalence of the discussion tends to be elided by mindless techno-utopianism on the one hand, or reactionary techno-scepticism on the other, resulting in a neglect of the human intersubjectivity of pedagogy. In reflecting on the use of mobile technologies in the classroom, Richard Davies' paper foregrounds the relational nature of communication in contemporary internet-associated technologies, arguing for a more detailed consideration of the affordances for frequent small scale social interactions in online learning. Between the levels of abstraction (Floridi 2011b) of information theory explored by Lundie and of user interface explored by Davies, distinct and at times contrary conclusions can be drawn about the potential of digital interactions for humanizing pedagogy. Finally, 
problematizing the focus on the human subject of many of the foregoing papers, Knox draws upon critical posthumanism to propose an analysis not of intersubjective interaction, but of 'intra-action' between human participants and web algorithms (Knox 2014). This conception rejects an instrumental view of technologies, helping to locate the posthuman subject both in embodied and virtual space. What is clear across this range of perspectives is the growing imperative of responsibility that demands that we take seriously the fact that, in the digital age the scale and scope of our actions have far greater capacity than they did for previous generations (Jonas 1984). Educational ideas can now go viral in ways that could hardly have been predicted.

With the emergence of MOOCs and continued impact of technology on educational culture, this issue represents a timely and much-needed reflective space upon the continual changes we see in the world around us. The distinct levels at which digital technologies may be examined - from the binary prima materia of data, up through algorithms and software platforms, to the socio-material impacts of technology in the classroom and wider society-suggest a research agenda for the future which brings together technical, normative and pedagogical sensitivities to address the uniquely human phenomenon of pedagogy.

\section{References}

Achterhuis, H. 2001. Introduction: American philosophers of technology. In American Philosophy of Technology, ed. H. Achterhuis and trans R. Crease. Bloomington: Indiana University Press.

Alder, G.S. 1998. Ethical issues in electronic performance monitoring: A consideration of deontological and teleological perspectives. Journal of Business Ethics 17(7): 729-743.

Biesta, G. 2005. Against Learning: Reclaiming a language for education in an age of learning. Nordisk Pedagogik 25(1): 54-66.

Biesta, G. 2006. Beyond learning: Democratic education for a human future. Colorado: Paradigm Publishers.

Bojesen, E. 2016. Inventing the educational subject in the 'Information Age'. Studies in Philosophy and Education. doi:10.1007/s11217-016-9519-2.

Boyatt, R., Joy, M., Rocks, C., and Sinclair, J. 2014. What (Use) is a MOOC?. In The 2nd international workshop on learning technology for education in cloud Springer Proceedings in complexity, 133-145.

Bradley, J. 2015. Stiegler Contra Robinson: On the hyper-solicitation of youth. Educational Philosophy and Theory 47(10): 1023-1038.

Davies, R. 2016. Ceaselessly exploring: Interactions in mobile mediated online learning. Studies in Philosophy and Education [this issue].

Ellul, J. 1964. The Technological Society, trans. J. Wilkinson. London: Jonathan Cape.

Floridi, L. 2011a. The informational nature of personal identity. Minds and Machines 21(4): 549-566.

Floridi, L. 2011b. The philosophy of information. Oxford: Oxford University Press.

Floridi, L. 2013. The ethics of information. Oxford: Oxford University Press.

Green, L. 2002. Technoculture. Crows Nest: Allen \& Unwin.

Hayles, N.K. 2012. How we think: Digital media and contemporary technogenesis. Chicago: University of Chicago Press.

Heidegger, M. 1977. The question concerning technology and other essays, trans. W. Lovitt. New York: Harper and Row.

Jonas, H. 1984. The imperative of responsibility. In search of an ethic for the technological age. Chicago: University of Chicago Press.

Kaplan, J. 2015. Humans need not apply: A guide to wealth and work in the age of artificial intelligence. New Haven, CT: Yale University Press.

Knox, J. 2014. Active algorithms: Sociomaterial spaces in the e-learning and digital cultures MOOC. Campus Virtualities, University in the Cloud Special Issue 3(1): 45-55.

Knox, J. 2016. Posthumanism and the MOOC: Opening the subject of digital education. Studies in Philosophy and Education. doi:10.1007/s11217-016-9516-5. 
Kouppanou, A. 2015. Bernard Stiegler's Philosophy of Technology: Invention, decision, and education in times of digitization. Educational Philosophy and Theory 47(10): 1110-1123.

Lewin, D. 2010. They know not what they do: The spiritual meaning of technological progress. Journal of Contemporary Religion 25(3): 347-362.

Lewin, D. 2012. Technology and the philosophy of religion. Newcastle: Cambridge Scholars Press.

Lewin, D. 2013. Technology. In Oxford handbook in theology and modern European thought, ed. George Pattison, Graham Ward, and Nick Adams. Oxford: Oxford University Press.

Lewin, D. 2016. The Pharmakon of Educational Technology: The disruptive power of attention in education. Studies in Philosophy and Education. doi:10.1007/s11217-016-9518-3.

Lundie, D. 2015. The givenness of the human learning experience and its incompatibility with information analytics. Educational Philosophy and Theory. doi:10.1080/00131857.2015.1052357.

Lundie, D. 2016. Authority, autonomy and automation: The irreducibility of pedagogy to information transactions. Studies in Philosophy and Education. doi:10.1007/s11217-016-9517-4.

Masschelein, J., and M. Simons. 2013. In defence of the school: A public issue. Leuven: Education, Culture and Society Publishers.

Plowman, L., and J. McPake. 2013. Seven myths about young children and technology. Childhood Education 89(1): 27-33.

Richtel, M. 2011. A Silicon Valley school that doesn't compute. http://www.nytimes.com/2011/10/23/ technology/at-waldorf-school-in-silicon-valley-technology-can-wait.html?pagewanted=all\&_r=0 (accessed February 16, 2016).

Stiegler, B. 1998. Technics and Time I: The fault of Epimetheus. Redwood, CA: Stanford University Press. Stiegler, B. 2010. Taking care of the youth and the generations. Redwood, CA: Stanford University Press. Stiegler, B. 2012. Relational ecology and the digital pharmakon. Culture Machine 13: 1-19.

Thomas, S. 2013. Technobiophilic: Nature and cyberspace. London: Bloomsbury.

Toffler, A. 1970. Future shock. New York: Random House.

University of Edinburgh MSc in E-learning. 2011. http://onlineteachingmanifesto.wordpress.com/ (accessed February 16, 2016).

Wicker, S., and D.E. Schrader. 2010. Privacy-aware design principles for information networks. Proceedings of the IEEE 99(2): 330-350. 